\title{
Global trends in the development of labour markets and employment in the focus of innovation change
}

\author{
Stanislava Pasieka ${ }^{1}$, Anna Pasieka $^{2}$, Mariana Bil $^{3, *}$, and Oleksandra Humeniuk ${ }^{4}$ \\ ${ }^{1}$ Cherkasy Bohdan Khmelnytsky National University, Department of Tourism, Cherkasy, Ukraine \\ ${ }^{2}$ Kyiv International University, Department of Economics, Kyiv, Ukraine \\ ${ }^{3}$ Institute of Regional Research named after M. I. Dolishniy, Department of Regions Development, Lviv, Ukraine \\ ${ }^{4}$ East European University of Economics and Management, Department of Economics, Cherkasy, Ukraine
}

\begin{abstract}
The article focuses on the main trends of innovation change effects on the labour markets and employment, value and mental characteristics, relation formation, regulation mechanisms, competitive relations, the distribution of rights and movement freedom, leading the formation of a new era of "the planet man" development. The world trends in the development of the labour markets and employment are analyzed. The ratification dynamics of international regulatory legal documents in the field of the world employment in 2006-2017 is investigated. Over 8,000 ratifications are found to be carried out by different states in 2017. This indicator increased constantly, gaining the highest rate acceleration in 2011-2012. Based on the United Nations Human Development Report, the polarization of the world's countries in terms of employment and unemployment (including among young people) is studied, with shares of employees less than $\$ 3.10$ of PPP per day. The lack of a direct correlation between the Human Development Index and the employment rate is established: the highest employment rate is found for a group of countries with a low index; it means that the improvement of the state employment policy should be oriented towards qualitative indicators. The structure of the employed by status is analyzed. On average, $54.8 \%$ of the world employed population is found to work on the basis of employment, and the higher the level of state development, the higher the proportion of such individuals. The analysis of GDP indicator per capita employed shows the high polarization of the modern world: the difference between countries with high- and low-income levels is about 25 times; this indicator for Ukraine is $47 \%$ of the world average and $18 \%$ of high-income countries. As a generalization of the analysis, the main problems of the development of the global labour market are considered and ways of their solution are proposed.
\end{abstract}

\section{Introduction}

Globalization is a bright trend in the development of a modern society. Despite the anti-globalization movements and the popularization of the globalization ideas, the planetary dimension of progress is accompanied by the formation of a single informational, financial-economic, educational, and labour-migratory space. The globalization processes have a great influence on the field of employment and labour market development. Its perceptible and debatable nature increases, because employment plays an increasingly important role for progressive changes in society. It is a socially significant process that provides every workable person with opportunities for self-realization, obtaining means of existence and meeting the needs of a higher order. The consequences of globalization effect on labour market and employment should be determined on the basis of the analysis of their development state in the different countries of the world. The difference or similarity between countries confirms their competitiveness in the global area of the free movement of resources.

\section{The aim and method used}

The aim of the article is to substantiate the priorities of solving the problems of global labour markets associated with the polarization of countries by their development level, migration processes, the effect of technologization on population unemployment. The justification is based on the analyze of global trends of labour markets and employment in terms of innovation changes.

The following methods of scientific investigation are used to find the key problems of labour markets and employment and to determine the effect of innovation changes on their development: the methods of analysis, synthesis, induction, deduction and generalization. To analyze the global trends of the development of labour markets and employment, the methods of statistic analysis are used. To determine the polarization of the world countries in terms of the investigated indicators, the method of comparative analysis is applied.

\section{Research results}

The globalization of the world has various impacts on the labour market and employment. Moreover, the latter

\footnotetext{
* Corresponding author: bmm1983@gmail.com
} 
plays its part in deepening the globalization processes. To systematize the innovation changes in employment and the development of labour markets, they can be classified in terms of trends:

1) the impact on value and mental characteristics of population transformed in various labour behaviour and the strategy of economic activity of population;

2) the impact on the formation of relations (at the local, regional, national, and global levels), primarily, social and labour ones with a distinction of geographical affiliation of the participants;

3 ) the influence on forms and possibilities of formation of relations: new technologies, distance communication, progressive logistics (the movement of necessary resources), the possibility of paying work and various services regardless of the place of stay, etc.;

4) the impact on the mechanisms of state regulation of labour markets and employment with the development of the joint regulatory legal field (international regulatory legal documents to defend the rights of working migrants and their family members), the introduction of common standards of social protection (the recognition of labour experience, education certificates), the implementation of open border policy and the exchange of labour force; 5 ) the impact on civil society with the spread of the rights and the freedoms of choice and displacement, with the constitutional consolidation of the determinants of human rights, the popularization of the ideas of free choice without the limitations of state borders (the main idea of the concept of human development);

6) the impact on the development of the joint market of separate spatial formations, regions involving crossborder space (as a rule, between border regions), international space (as a rule, two or few neighboring states);

7) the impact on competitive relations with the formation of additional competition in the domestic market (resources, business, labour) by the subjects of other countries.

In fact, we are living in the era of "the planet man" development. This idea does not always find favour among most members of the society, however, it is quite acceptable for young people. Such inclinations are observed in Ukraine. With the possibility of frequent movements in different countries, the working life of a person becomes geographically distinct with being born in one place, studying in another, employment in another, etc. This situation changes starting principles of development in terms of labour markets and employment. Shifting of the emphasis on a person, his/her labour potential destroys ethnic homogeneity and national identity. The identity, not even social but economic, becomes advanced with belonging to a certain social-labour system in the limited time coordinates. In addition, the spatial relationships of investment in human capital and the economic benefits of their implementation are destroyed.

Since earlier, it was possible to talk about the negative consequences of leaving a state (region) for the young people educated for the state budget, at present, this situation is regular. The question is not in the loss of human capital, but whether it is compensated by the circulation of labour potential. Such circulations are manifested in the return after departure and the arrival of persons from other social systems.

The main global trends in the development of labour market and employment should be considered. They are studied by the Ukrainian scholars not as often as internal processes in the labour market, but remain an actual object of research, in particular, in terms of international comparison and foreign experience study. Although the situation in Ukraine concerning the development of labour market and employment is often considered critically, it is necessary to realize that it is stipulated by: - first, the established criticism of scientific and social thinking with rejection (subconscious ignoring) of positive achievements;

- second, the geopolitical position of our state with the neighbourhood of more developed states, which is a serious challenge and risk of labour potential loss.

Despite the competitive loss of the labour market in Ukraine to neighbouring and other EU countries, the great advantage is its location on the European continent with long traditions of economic activity, the consolidation of human rights and democratic principles. If thinking globally, there are still many more problematic societies in the world where employment opportunities are very limited. The international community represented by international organizations, in particular the International Labour Organization, the International Organization for Migration, is making significant efforts to promote the ideas of decent labour, maximum inclusion of people in various activities, regardless of labour ability (employment opportunities for people with special needs). A particular problem is the violations of children's labour caused by the interests of the shadow business involving those determining the behaviour of market entities with savings in all items of expenditure [1].

The main actions of international organizations, power structures of the leading countries of the world are the formation of the common regulatory legal field. The NORMLEX information portal presents interesting data on the number of the ratified international regulatory legal documents related to the employment field and supported by the International Labour Organization. Fig. 1 shows that over 8,000 ratifications were made by different countries in 2017. The indicator constantly increased gaining the highest rate acceleration in 20112012.

It is interesting to note that a large number of countries in the world ratified the following conventions [2]:

- Convention on Prohibition and Immediate Action for Elimination of the Worst Forms of Child Labour No. 182, 1999 (181 countries);

- Convention on Forced or Compulsory Labour No. 29, 1930 (178 countries);

- Convention on Discrimination in the Field of Labour and Occupation No. 111, 1975 (175 countries);

- Convention on the Equal Remuneration of Men and Women No. 100, 1957 (173 countries);

- Convention on Minimum Age for Employment No. 138, 1973 (170 countries). 


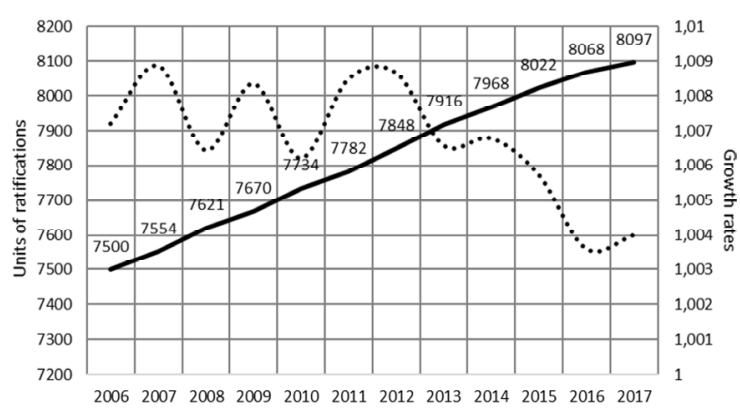

Fig. 1. Ratification of international regulatory legal documents in the sphere of the world employment in 2006-2017 [2].

These documents have a long period of action. Some of them have been updated with additional protocols. Ukraine ratified the mentioned international regulatory legal actions. Their implementation in the national scientific field enables the rights of the population in the field of employment to be defended, even under the conditions of an underdeveloped judicial system, through appeals to international human rights tribunals.

The global trends in the development of labour market and employment should be analyzed. In the average world dimension there are a lot of problems. According to R. Stakanov, in the second decade of the XXI century, significant imbalances persist on the global labour market, which became particularly acute with the beginning of the global economic crisis of 2008; the volumes of unemployment remain significant, the categories of workers who remain unemployed for a long time expand in absolute terms; there are high unemployment rates among young people rising sharply after 2008; the greatest danger for global economic development is the reduction of employment among highly skilled workers, whose labour productivity growth is crucial for the sustainable development in post-industrial societies [3].

That is, there are a lot of problems to be solved in contrast to the rapid development of the world labour market as a result of active mobility growth of labour and capital being two determining production factors [4]. According to the analysis results of the world labour market, K.Petrenko and V. Pihul drew a conclusion that it is characterized by the following main tendencies: the growth of the world unemployment caused by the crisis and new technology development; the prevailing increase on the employed in the service sector and decrease in industry and agruculture; the growth of migration and "brain drain" [4].

The urgent problem of the development of the world labour market is the polarization of countries by the level of their development. This problem should be considered not only in terms of the limited labour and development opportunities in poorer societies. Such a difference is distructive for the developed societies as well. According to $\mathrm{V}$. Osokin and N. Rudenko, a negative result of globalization impact of the world economy on the development of national labour markets is the preservation of the updated employment structure as a result of the opportunities to realize the interests of the economically developed countries in the system of international labour distribution, the imbalance of structural changes in tranformation economies with the requirements of the innovative changes [5]. That is, the low developed societies in the conditions of forming the global space and the redistribution of human resources, slow down qualitative progressive changes and make international organizations spend significant efforts to overcome the gaps.

The Human Development Index (HDI) in evaluating part of labour and employment is authoritative source of statistic data. The global situation is clearly demonstrated by the comparison between the groups of countries. The comparison of employment rate indicator in 2017 may be an example of it in the context of the countries divided according to the level of human development (Ukraine is included to the group of countries with the high level of human development due to the high level of education indicators). This indicator is taken into account when calculating the Human Development Index. Fig. 2 shows that the value of the employment rate indicator is not decisive for the development of the country. The group of countries with a very high indicator of human development is provided with this advantage by rather qualitative indicators of economic activity and life activity of the society than quantitative ones. These are the level of education and volumes of GNI (Norway, Australia, Switzerland, Germany, Denmark, Singapore, the Netherlands, etc.). The level of employment is considerably higher by $6.7 \%$, on average, for the countries with a high level of human development indicator including Ukraine; however, it is not fully transformed into the indicators of economic and innovative development.

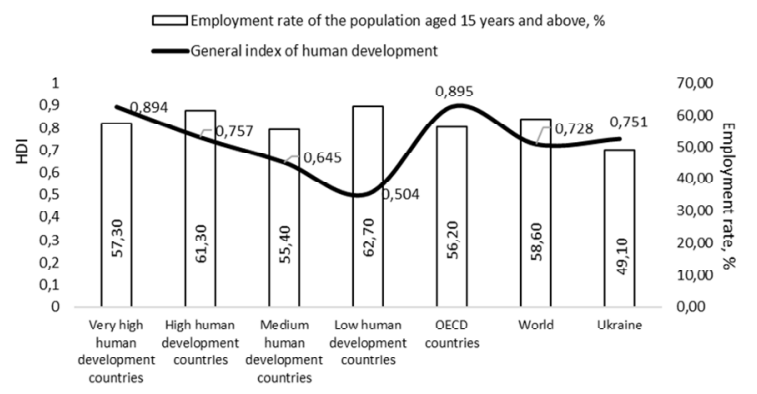

Fig. 2. Employment level in different groups of countries in the ratio to the Human Development Index, 2017 [6].

The highest level of employment is characteristic for the countries with the low level of human development (Swaziland, Syria, Angola, Tanzania, Nigeria, Cameroon, etc. out of 148 ranking positions). These results may be partly stipulated by the biased statistical accounting, and partly, by the preservation of the backward (pre-industrial) forms of employment in industry and agriculture. It is interesting to compare the results to the indicator, which is also monitored in the calculation of the Human Development Index. It is the number of employees working for less than $\$ 3.10$ of PPP per day ( $0 \%$ of the employed population). This indicator is not found for the countries with very high Human Development Index and the countries of OECD group. Fig. 3 shows the situation for the rest of the analyzed groups of countries. 


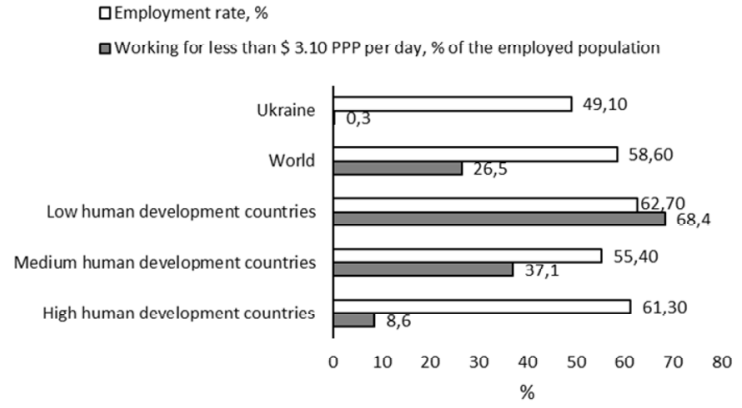

Fig. 3. Share of employees working for less than $\$ 3.10$ of PPP per day ( $0 \%$ of the employed population) and employment level in different groups of countries in the world, 2017 [6].

According to the official data, the proportion of the employed population receiving less than \$ 3.10 of PPP per day is $68.4 \%$ for countries with a low human development indicator. It is a very high indicator, which clearly shows how polarized is the modern world according to the level of socio-economic development. It has a direct impact on the labour markets and employment in the global dimension. It is rather difficult to speak about the opportunities of labour potential development, self-realization, continuous development with the investments into personal human capital, the formation of social capital, etc. with the low level of wages. The value of the indicator for the share of employees for less than $\$ 3.10$ of PPP per day is amazing for such countries as Burundi, Mozambique, Afghanistan, Liberia, and Niger. In the group of countries with a high level of human development including Ukraine, the highest values are found for Peru, Turkey, Georgia, Mongolia, Macedonia, the Dominican Republic. Thinking globally, about $30 \%$ of the population in the world earns less than $\$ 3.10$ of PPP per day. The share of these individuals in Ukraine is rather low. We think that larger problem for our state is the biased representation of the real wage level by the domestic statistics. The shadow wage system has become very firm in Ukraine. Therefore, there is a lack of comparability for the indicators of population poverty to social tension (self-esteem of their material well-being by households), on the one hand, and a relatively low share of low-paid workers, on the other hand, which is, however, a satisfactory indicator if compared with neighbouring countries.

In the framework of the Human Development Index calculation, the indicators of employment level in the context of the agro-industrial complex and services sector are also relevant for the analysis of innovative changes in the development of labour markets. The global trend for the increase of the employed share in the field of service is clear and understandable. However, there are certain threats in it. World crisis situations show that the countries with dominating service sector (for example, tourism) in economy suffer from global currency fluctuations and financial market crisis the most. The material sector of production still needs to remain the core of the economy, serving as a stabilizer during the periods of cyclical fluctuations and crisis situations. This area of employment is specific. Under conditions of insufficient level of technological development, it requires the skilled working personnel, which is often a deficit in ineffective motivation. In the conditions of a high level of technological development, on the contrary, there is a problem of replacing the workforce with automated and robotic systems. In any case, the employment of the material sector should be regulated in a segment and oriented, first of all, to increase productivity. Other approach is marketing, with a main focus on the finished material product, which is difficult to represent in the service sector. Another relevant indicator is the unemployment rate, including among young people. The situation regarding this indicator of the development level of labour market is extremely variegated in different countries around the world (Fig. 4). International comparisons regarding unemployment are particularly significant for the Ukrainian society. In 2017, the official unemployment rate among young people in Ukraine was $23.3 \%$ being higher than the average world value. The indicator is $12.2 \%$ for the countries with a very low rate of the human development, but it is not sufficiently representative, since accounting is carried out in a very limited number of countries. That is, Ukraine in this regard is a "leader" from the negative side, although rather high unemployment rate among young people is also characteristic for many countries in the group with a very high and high Human Development Index. This indicator varies significantly for the countries of different groups. For example, there are fluctuations in the range of $42.8 \%$ (Greece) - $0.5 \%$ (Qatar) in the group of countries with a very high unemployment rate of young people.

Other countries with high rate of unemployment among young people are the following: - countries in the group with very high index: Greece, Spain, Croatia, Italy, Montenegro, Cyprus, Saudi Arabia, Portugal, France, Finland, Belgium, Ireland, Sweden; - countries in the group with high index: Bosnia and Herzegovina, Libya, Macedonia, Saint Lucia, Serbia, Armenia, Tunisia, Jordan, Albania;

- countries in the group with medium index: Republic of South Africa, Namibia, Palestine State, Gabon, Egypt, Iraq;

- countries in the group with low index: Swaziland, Solomon Islands, Mauritania, Gambia, Mozambique.

The increased unemployment among young people for most countries with high Human Development Index is determined by additional pressure on the internal labour markets by migrants. The tendency to extending working life has an additional effect complicating the access of young people to workplaces. That is, the problem of youth employment being one of the most urgent in Ukraine, is a major problem for many societies. However, if a high share of the unemployed youth for the countries with the developed labour markets is a sigh of high competition and pressure on vacant workplaces, this situation is a risk of migration loss for the countries with lower competition signs. Youth emigration compared to other age categories causes very strong negative impact on the development opportunities of a country starting with the aspects of demographic 
reproduction and completing with the issues of sociocultural unity.

口Unemployment rate,\% to economically active population

u Unemployment rate of youth, $15-24$ years old, $\%$

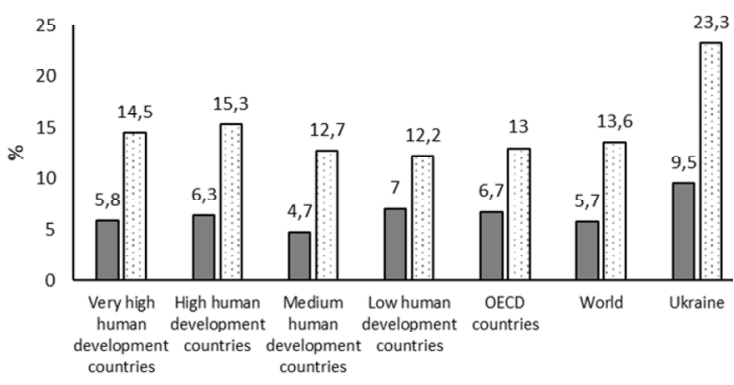

Fig. 4. Unemployment level including among youth in different groups of the world countries, 2017 [6].

The analyzed indicators being considered in calculating the Human Development Index show the variety of international situation in terms of the state of labour market and employment structure. If one imagines the functioning of the global labour market without any borders, this "step" would be disastrous in the current situation. At present, international organizations need to make significant efforts to reduce the uneven social and economic development among countries. An important conclusion of the analysis of the Human Development Index is the lack of correlation between the employment level and the human development level; the highest employment level is found for the group of countries with the low level of the Human Development Index. It means that the improvement of the state employment policy should be oriented on qualitative indicators. It is not a matter of demonstrating relatively high rates of employment and low unemployment rates. It is necessary to compare their dynamics, including the types of economic activities, economic indicators, in particular, GNI per capita, to take into account the results of innovative activity, the income level of the population, etc.

The indicators of the Human Development Index show the main processes of labour markets and employment. The Internet resource of "ILOSTAT" International Labour Organization forms rather powerful information basis. The structure of employment for economy sectors and a lot of other indicators can be analyzed according to its data. The correlation analysis of the employed by status is interesting in terms of identifying innovative changes in the labour market. The data of 2016 show that on average $54.8 \%$ of the total number of the employed people worked on a basis of employment, with what the higher level of the country development, the higher the share of such individuals (Fig. 5). That is, in spite of the importance of selfemployment and entrepreneurship, the bulk of the economically active population needs job offers. In the developed countries, these are usually large corporations, on the one hand, and the subjects of small and medium businesses, on the other. In the countries with a transformational economy, employment on an employment basis maintains weight in the public sector.
Typically, these are large industrial enterprises. Besides, agricultural enterprises are characterized by sufficient weight, where the low level of technology still retains a high demand for labour forces (manual work).

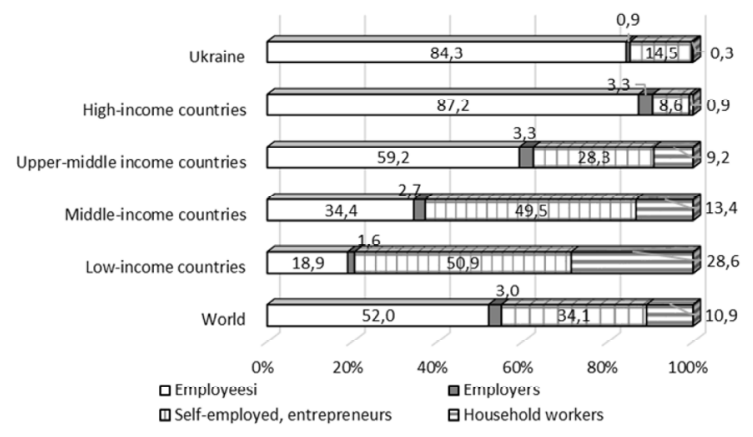

Fig. 5. Structure of the employed population by status in the different groups of countries, Nov. 2018 [7].

Fig. 5 shows that the share of the employed in households increases for the countries with lower income level. As a rule, it is a matter of personal peasant farms. The share of the employed from the analyzed indicators for Ukraine is closer to the value of the developed countries. At the same time, the role of employers needs to be increased. Ukraine has relatively high indicator of self-employment that is partly stipulated by the popularization of employment in IT. That is, the stimulation of entrepreneurship should be directed more towards small and medium business.

The transformation relevance of quantitative indicators into qualitative ones was pointed out in the analysis of the global tendencies in the development of labour market. It means that the issue is not to maximize the employment level but to represent these indicators in the results of economic and social effects. The indicator of GDP per capita employed presented by "ILOSTAT" allows analyzing the global tendencies in the context of economic effects. Fig. 6 shows to what extent the modern world is polarized. The difference between the countries with high- and low-income levels is almost 25 times. The GDP per capita employed of Ukraine is $47 \%$ of the world average value and $18 \%$ of the countries with high income. According to this indicator, our state belongs to the group of middle-income countries. However, the neighbourhood with the countries of the high-income group forces to counteract migratory losses and to mobilize resources to improve the qualitative labour results of the economically active population of Ukraine.

To draw a definite conclusion in the analysis of global trends in the development of labour market and employment, the main problems being urgent in the innovative aspect should be determined (Table 1). The problem of structural transformations of employment in the developed countries with staff shortage is worth paying attention. This problem requires a more detailed description. The labour markets of the developed countries are known to develop more dynamically. The demands of decent labour for these countries are selfevident, while adhering to at least basic safety standards is a major achievement for poor countries. Such 
conditions complicate high-quality professional training in different countries and the redistribution of personnel from some social and labour systems to others. While professions in entirely new spheres of activity become relevant for the developed countries, labour donor countries cannot meet this demand. For example, the British newspaper "The Telegraph" named the most needed and well-paid professions in 20 years; they are: the architect of virtual objects; guardian at home; health advisor; creator of the body part; specialist in nanomedicine; physician who deals with memory issues; personal therapeutic assistant; designer of children (genetics); planter of vertical technology; specialist in cleaning up computers and mobile phones from redundant data; avatar designer; power amplifier; the programmer is a touch-interface [9]. If the need for such professions is strengthened, such new niches will become very scarce for the labour markets that satisfy most professional positions at the expense of migrants. Therefore, the development of the global labour market should be coordinated with educational processes, providing for promising areas of employment and, if possible, preparing a staffing reserve in advance.

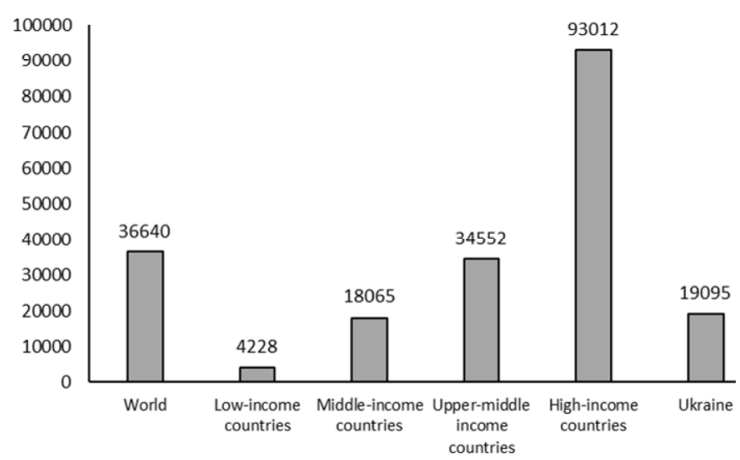

Fig. 6. GDP per capita employed in different groups of the world countries USD PPP, Nov. 2018 [8].

Table 1. Main development problems of the world labour market

\begin{tabular}{|c|c|c|c|}
\hline No & Problem & Problem content & Problem solving \\
\hline 1 & $\begin{array}{l}\text { Sensitivity of } \\
\text { national } \\
\text { (regional) } \\
\text { labour markets } \\
\text { to global crisis } \\
\text { phenomena }\end{array}$ & $\begin{array}{l}\text { The strong dependence } \\
\text { of domestic labour } \\
\text { markets on related areas } \\
\text { - financial, investment, } \\
\text { political (including } \\
\text { military conflicts, social } \\
\text { explosions) greatly } \\
\text { destabilizes the situation } \\
\text { in the context of global } \\
\text { problems }\end{array}$ & $\begin{array}{l}\text { Implementation of an } \\
\text { effective state } \\
\text { employment policy } \\
\text { with the formation of } \\
\text { resource reserves } \\
\text { during the periods of } \\
\text { global crisis change }\end{array}$ \\
\hline 2 & $\begin{array}{l}\text { Social } \\
\text { polarization of } \\
\text { the world } \\
\text { countries }\end{array}$ & $\begin{array}{l}\text { Significant gaps among } \\
\text { the countries in terms of } \\
\text { their development } \\
\text { determine different } \\
\text { labour opportunities, } \\
\text { business idea } \\
\text { implementation, creative } \\
\text { activity that violate the } \\
\text { human rights relating the } \\
\text { development of a } \\
\text { personality }\end{array}$ & $\begin{array}{l}\text { Creating opportunities } \\
\text { for relocation between } \\
\text { regions and countries } \\
\text { in order to find better } \\
\text { working conditions, } \\
\text { learning, and business }\end{array}$ \\
\hline 3 & $\begin{array}{l}\text { Labour- } \\
\text { migration } \\
\text { concentration in } \\
\text { the most }\end{array}$ & $\begin{array}{l}\text { The attractiveness of the } \\
\text { most developed labour } \\
\text { markets for labour and } \\
\text { education migrants }\end{array}$ & $\begin{array}{l}\text { Implementation of the } \\
\text { efficient state } \\
\text { migrative policy } \\
\text { limiting immigrate }\end{array}$ \\
\hline
\end{tabular}

\begin{tabular}{|c|c|c|c|}
\hline $\mathrm{No}$ & Problem & Problem content & Problem solving \\
\hline & $\begin{array}{l}\text { developed } \\
\text { countries of the } \\
\text { world }\end{array}$ & $\begin{array}{l}\text { exerts excessive pressure } \\
\text { on their infrastructure } \\
\text { and polarizes different } \\
\text { countries of the world } \\
\text { even more in terms of } \\
\text { their development }\end{array}$ & $\begin{array}{l}\text { processes and partial } \\
\text { protectionism of the } \\
\text { labour rights of the } \\
\text { permanent population }\end{array}$ \\
\hline 4 & $\begin{array}{l}\text { Growth of } \\
\text { unemployment } \\
\text { in the conditions } \\
\text { of technological } \\
\text { progress }\end{array}$ & $\begin{array}{l}\text { The spread of } \\
\text { automation and robotics } \\
\text { technology reduces the } \\
\text { demand for human } \\
\text { labour }\end{array}$ & $\begin{array}{l}\text { Development of } \\
\text { employment spheres, } \\
\text { in which human } \\
\text { labour cannot be } \\
\text { replaced by } \\
\text { technologies and } \\
\text { which provide an } \\
\text { opportunity for self- } \\
\text { realization }\end{array}$ \\
\hline 5 & $\begin{array}{l}\text { Structural } \\
\text { transformations } \\
\text { of employment } \\
\text { in the developed } \\
\text { countries with } \\
\text { staff shortage }\end{array}$ & $\begin{array}{l}\text { Progressive development } \\
\text { of innovative activities in } \\
\text { the developed countries } \\
\text { significantly increases } \\
\text { the demand for } \\
\text { professional staff, which } \\
\text { cannot be fully satisfied } \\
\text { with migration factor } \\
\text { since such qualifications } \\
\text { are not yet available in } \\
\text { less developed countries, } \\
\text { labour force donors }\end{array}$ & $\begin{array}{l}\text { Strengthening the } \\
\text { prognostic orientation } \\
\text { of the educational } \\
\text { training of specialists } \\
\text { and the spread of } \\
\text { training practice to a } \\
\text { specific employer }\end{array}$ \\
\hline 6 & $\begin{array}{l}\text { Structural } \\
\text { deformations in } \\
\text { favour of } \\
\text { employment, } \\
\text { entrepreneurship } \\
\text { in the service } \\
\text { sector }\end{array}$ & $\begin{array}{l}\text { Excessive inclination for } \\
\text { employment and } \\
\text { entrepreneurship in the } \\
\text { services sector is due to } \\
\text { the dominance of small } \\
\text { and medium businesses, } \\
\text { faster return on } \\
\text { investment and creativity } \\
\text { for the employed, which, } \\
\text { however, weakens the } \\
\text { productive sector and } \\
\text { makes the economy } \\
\text { more sensitive to various } \\
\text { crisis pressures }\end{array}$ & $\begin{array}{l}\text { Targeted stimulation } \\
\text { of the development of } \\
\text { the material } \\
\text { employment sector } \\
\text { with the production of } \\
\text { goods oriented to } \\
\text { meeting the needs of } \\
\text { the highest order in } \\
\text { comparison with most } \\
\text { services }\end{array}$ \\
\hline 7 & $\begin{array}{l}\text { The complexity } \\
\text { of youth } \\
\text { employment } \\
\text { (first job) }\end{array}$ & $\begin{array}{l}\text { High pressure on internal } \\
\text { labour markets by } \\
\text { migrants leads to } \\
\text { difficulties in finding } \\
\text { employment for young } \\
\text { people, even in the } \\
\text { countries with the high } \\
\text { Human Development } \\
\text { Index }\end{array}$ & $\begin{array}{l}\text { Realization of } \\
\text { targeted programs } \\
\text { guaranteeing the first } \\
\text { job, especially for the } \\
\text { countries being in the } \\
\text { risk group of } \\
\text { migration loss }\end{array}$ \\
\hline
\end{tabular}

\section{Conclusions}

Consequently, the world labour market develops in twovector direction: in a holistic orientation towards the goal of sustainable and human development, and separated with the specific priorities of different countries and integrational entities. Globalization in the field of labour and employment is accompanied by the intensification of migration processes. According to official data, the share of international migrants is now about $3 \%$ of the world population.

The share of migrants in the population structure is enormous for many societies. The indicators of some European countries may be an example for it: Liechtenstein 63\%, Andorra 60\%, Monaco 56\%, Luxembourg 44\%, Switzerland 29\%, Ukraine 14\% [10]. The issue of improving the competitiveness of the domestic labour market is on the agenda for most countries, including Ukraine, in order not to lose labour 
potential, especially young people, with high migration activity of the population. Therefore, marketing approaches are very necessary in this regard. Their actualization for Ukraine is conditioned by the need for application at different levels and with different participants. The objectives of such instrumental influences must be formed based on the analysis of factors that determine the development of the Ukrainian labour market in the context of global transformation of employment being the subject of further research by the authors.

\section{References}

1. Mulska, O.P.: Ryzyky poshyrennia vykorystannia dytiachoi pratsi $\mathrm{V}$ rehioni, na prykladi Lvivskoi oblasti (Risks of the spread of child labour in the region, on the example of the Lviv region). Ukrainskyi sotsium. 2, 95-106 (2012)

2. NORMLEX - Information System on International Labour Standards. http://www.ilo.org/dyn/normlex/en/f?p=NORMLEX PUB:1:0::NO::: (2019). Accessed 10 January 2019

3. Stakanov, R.D.: Hlobalnyi rynok pratsi v konteksti mizhnarodnoi trudovoi mihratsii (The Global Labour Market in the Context of International Labour Migration). Aktualni problemy mizhnarodnykh vidnosyn. 115, 94-99 (2013)

4. Petrenko, K.V., Pihul, V.V.: Osoblyvosti formuvannia ta rozvytku svitovoho rynku pratsi (The features of formation and development of the world labor market). Biznes Inform. 12, 37-42 (2015)

5. Osokina, V.V., Rudenko, N.V.: Vplyv hlobalizatsii svitovoi ekonomiky na rozvytok natsionalnykh rynkiv pratsi (The impact of the world economy globalization on the local markets development). Stratehiia rozvytku Ukrainy, 1, 150-153 (2011)

6. Human Development Report 2018. Human Development for Everyone. The United Nations Development Programme (UNDP). http://hdr.undp.org/sites/default/files/2018 human d evelopment_statistical_update.pdf (2018). Accessed 10 January $\overline{2} 019$

7. Employment distribution by status in employment (by sex) - ILO modelled estimates, November 2018. International Labour Organization. https://www.ilo.org/ilostat/faces/oracle/webcenter/p ortalapp/pagehierarchy/Page27.jspx?subject=ILOES T\&indicator=EMP_2EMP_SEX_STE_DT\&dataset Code $=$ A\& collectionCode $=$ ILOEST (2018) Accessed 15 April 2019

8. Labour productivity - Output per worker (GDP constant 2011 international $\$$ in PPP) - ILO modelled estimates, November 2018. International Labour Organization. https://www.ilo.org/ilostat/faces/oracle/webcenter/p ortalapp/pagehierarchy/Page27.jspx?subject=LPY\&i ndicator=GDP_211P_NOC_NB\&datasetCode $=$ A\&c
ollectionCode=ILOEST (2018). Accessed 15 April 2019

9. Komuda, L.: Zawody i umiejętności przyszłości (Occupations and skills of the future). https://pracaenter.pl/czytelnia/2621/zawody-i-umiejetnosciprzyszlosci (2013). Accessed 15 January 2019

10. International migration report highlights 2015 . United Nations, New York. http://www.un.org/en/development/desa/population/ migration/publications/migrationreport/docs/Migrati onReport2015_Highlights.pdf (2016). Accessed 15 January 2019 